\title{
The Effect Of Hedonic Motivation Towards Online Impulsive Buying With The Moderating Effect Of Age
}

\author{
M.Ruby EVANGELIN ${ }^{*}$, A.Navitha SULTHANA ${ }^{2}$, Dr.S.Vasantha ${ }^{3}$ \\ ${ }^{1}$ Assistant Professor and Research Scholar, School of Management Studies, Vels Institute of Science Technology and \\ Advanced Studies (VISTAS), Chennai. Email : rubyevangelin.sms@velsuniv.ac.in \\ ${ }^{2}$ Ph.D. Research Scholar, School of Management Studies, Vels Institute Of Science, Technology \&amp; Advanced Studies \\ (VISTAS), Pallavaram, Chennai. Email:navitha.sulthana@gmail.com \\ ${ }^{3}$ Professor, School of Management Studies, Vels Institute of Science Technology and Advanced Studies (VISTAS), \\ Chennai. Email : vasantha.sms@velsuniv.ac.in \\ ${ }^{*}$ Corresponding Author
}

\section{Received: 10.08.2021 Accepted: 11.08.2021 Published: 16.10.2021 DOI: $\underline{\text { 10.47750/QAS/22.184.31 }}$}

\begin{abstract}
Impulsive buying is adopted by the larger proportion of the customer's shopping tendency in brick and motor retail markets. Online merchants also try to attract customers to make online purchases, which will lead the customer to make an unplanned purchase. the hedonic motivation plays a vital role among the customers which plays a key role to change the shopping behavior of the customers to make an impulsive purchase. the study also proves the moderating effect of age between hedonistic shopping motivation and online impulsive buying. The questionnaire was circulated to the respondents, where 421 respondents responded to the survey. Andrew Hayes's process was administered to check the moderating effect of thisresearch study variables. . The conclusion of the research study is the hedonic shopping motivationshows a vivacious role in the shopping behavior of the customer. With the combination of the marketing strategy and hedonic shopping motivation of the customers, several new thoughts are offered to enrich the understanding of the factors of online impulsive buying
\end{abstract}

Keywords: hedonic shopping motivation, Impulsive buying, marketing strategy, online impulsive buying, shopping tendency

\section{Introduction}

The growth of technology has changed the shopping behavior of the customers. The customers tend to buy the product which they view on the websites and tend to make an unplanned purchase. The internet has given an outstretched arm for the marketers to introduce new products and services for the customer through the shopping portals, which in turn will influence the customer to make an impulsive purchase. nowadays the customers tend to have a shopping behavior which not only influences to make the right purchase but also helps the customer to have a wonderful shopping experience. The customer undergoes two different emotions when they purchase online, such as Hedonic Motivation and Impulsive buying. These two emotions influence the emotional state of the customer whenever they opt to make an online purchase (Navitha 2020)

These days the e-commerce attracts customers in today's scenario. Web-based shopping gives clients to improve their proficiency in shopping since they don't need to spend much time going out to a retail store, the customers spend their quality time sitting at home and making a purchase with these online shopping portals (Ayu and Lahmi,2020). The retail organizations make sites that fill in as a mechanism for likely clients to collaborate and do exchanges, in this manner making shopping simpler. The website quality strategy was embraced to gauge the nature of a site. It is a service quality advancement, broadly used to catch buyer assumptions and discernments accepted to address administration quality (Baber, 2019).One of the elements that influence an individual shopping experience is Hedonic motivation. It is an inspiration that indicates a feeling of joy, dream, social and enthusiastic broadness. Hedonic motivation rises out of clients' encounters, especially while shopping on the web (Botti and McGill, 2021).

A good quality online shopping website guarantees that customers can interface openly. One type of hedonic motivation intelligent cycle in internet shopping is perusing, which prompts drive purchasing, basically suggesting enjoying spontaneous buys without considering the advantages of the merchandise acquired (Gültekin and Hacettepe, 2012). Thus, online impulsive buyingis made because of the positive result knowledgeable during the hedonic motivation on the site. It additionally happens when somebody is perusing either for amusement only or unwinding (Hashmi, Attiq, and Rasheed, 2019).

Online shopping is a pleasant and fun-filled activity for the customers. This sort of shopping induces the customers to make an unplanned purchase very frequently. Online impulsive buying is behavior that makes the customer buy goods or services unplanned or spontaneously. This online 
impulsive buying is not restricted to few categories, but it applies to all goods and services. (Pandey, 2017). Yistiani (2012), expressed that Online impulsive buying is frequently impacted by a few things in which thehedonic motivation plays the main part. It shows buyers might be associated with motivation purchasing. If they are roused on hedonic characteristics in contrast to delight, dream, and enthusiastic fulfillment. Since the shopping experience incorporates libertine necessities, the item is to be bought seems, by all accounts, to be picked without earlier arranging. In this way, buyers will make a drive purchasing occasion.

Hedonic shopping encounters that clients need are interminable.Researchers have since a long time ago perceived the expected worth of hedonic shopping motivations. Hedonic qualities and utilization propensities are credited to the conduct that gets multisensory, emotive, and dream components of purchasing and utilization(Ayaz Samo2019).It is tracked down that a few customers, particularly ladies view shopping as an outflow of affection. Hedonic shopping is depicted as the benefits of securing energy and delight while participating in shopping items and administrations. It is additionally considered that an advanced shopping climate concerning feelings, temperaments, and dreams is the key driving element of shopping enjoyment. Thus the paper investigates the influence of hedonic motivation towards online impulsive buying and also the study brig out the impact of Age of the customer as a moderator between hedonic motivation and online impulsive buying.

\section{Objectives of the Study}

a. To study the effect of Hedonic Shopping motivation towards online impulsive buying

b. To analyse a moderating effect of moderating effect of age between hedonic motivation and online impulsive buying

\section{Conceptual Framework}

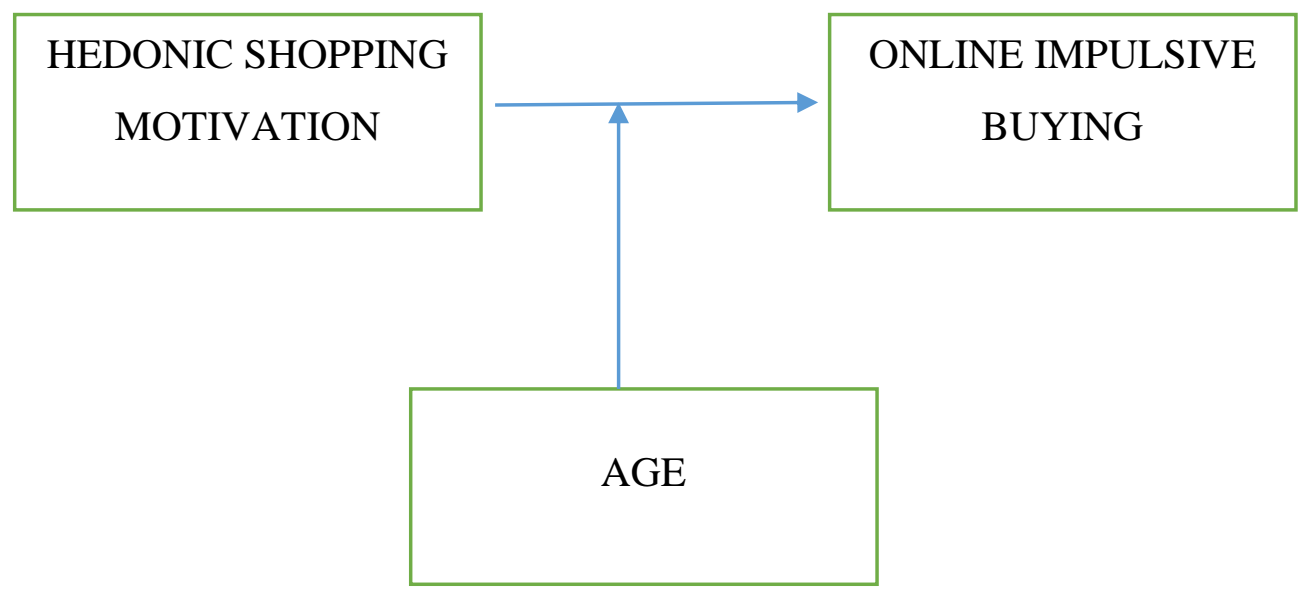

\section{Review of literature}

\subsection{Hedonic Shopping Motivation}

Hedonic shopping motivation is the internal motivation of the customers to make a purchase. During the purchase, the customers tend to get excited and try to change the mood and also helps the customers to reduce boredom(Sari,2019). Hedonic shopping motivation, where the customers will shop because the individual feels delighted and feel that shopping is a fascinating thing. Subsequently, this motivation depends on abstract or passionate deduction as it incorporates passionate reactions, arousing joys, dreams, and tasteful contemplations. Along these lines, hedonic motivation is the motivation of customers to look for shopping is a delight in itself so as not to focus on the advantages of items bought (Mamuaya,2019).

Motivation towards shopping is explicitly partitioned into two, utilitarian and Hedonic Motivation. Hedonic Shopping Motivation is an individual's longing to shop to satisfy mental requirements, in particular feeling, fulfillment, eminence, what's more, other emotional sentiments. Thus, it appears to meet unnecessary social, stylish, and way of life request (Ha, 2020)

$\mathrm{H} 1$ : There is a significant difference between Age and Hedonic Shopping Motivation

\subsection{Online Impulsive Buying}

Motivation purchasing conduct is considered as a significant point and portrayed in various manners by showcasing researchers. As per Akram 2018, in the beginning, phase of exploration, it was portrayed as spontaneous what's more, prompt buy conduct while shopping yet later an impromptu activity was perceived as not quite the same as a spontaneous purchasing Salman Kimiagari 2021. Zhang 2018 referenced that motivation purchasing conduct is associated with an abrupt purchasing, joined by unmistakable inclinations of energy and happiness. AmmarHussain 2021 announced drive purchasing conduct as an activity of buying an item without arranged activity and conduct appeared preceding a genuine purchasing. Hastiness/Impulsive purchasing conduct is depicted as "Customers inclination to purchase right away, unreflectively, actively and suddenly". According to Yu-Qian Zhu 2020, Numerous analysts have given significant consideration to purchaser's motivation purchasing and indiscretion characteristics, both in the on the web and customary shopping store As indicated by Zhang 2018 numerous characteristics impact web-based shopping settings, and aim to purchase online is expanding because of indiscretion.

H2: There is a significant difference between Online Impulsive Buying and Hedonic Shopping Motivation 


\subsection{Moderating Effect Of Age Between Hedonic Motivation And Online Impulsive Buying}

Few researchers initiate that the demographic variable such as gender, income, age, educational qualification, browsing times affects the buying behavior of the customers. The Study variable taken to find the moderating effect is Age which proves that it might have a positive or negative exposure over the buying behavior of the customers. Age-related contrasts in customer conduct are the consequence of physical and intellectual maturing measures and collected beneficial encounters [Sharma 2012]. Age-related adjusts make more established shoppers' perspective-making cycles and propensities not the same as those of more youthful grown-ups [Cole et al. 2008]. A few speculations are proposed to clarify the likely directing impact old enough on the connection between quality discernments and saw esteem [Sharma, 2012]. The previous study proves that Age factors influence hedonic shopping motivation, the age groups tend to differ and their level of motivation to make purchases online. As shown by Jiaming Fang 2017, data handling capacity contrasts among more youthful and more seasoned shoppers may arise under some less apparent errand conditions or missing in others. The previously mentioned data measure contrasts among more youthful and more seasoned customers are directed by inspiration and capacity. (ZakariaWahab 2018)

H3: There is a significant moderating effect of Age between Hedonic shopping motivation and Online Impulsive Buying.

\section{Research Methodology}

The researchers have designed the questionnaire for examining "Influence of hedonic motivation towards online impulsive buying with the moderating effect of Age". The descriptive research design was adopted and convenience sampling was used by the research for conducting the survey. The questionnaire was circulated to respondents who use online shopping to buy their desired products. The random sampling technique was administered to circulate the questionnaire among 421 respondents for collecting the primary data.

\begin{tabular}{|l|l|l|l|}
\hline S.no & Variable Name & Number of Items & Sources \\
\hline 1 & Hedonic Shopping Motivation & 7 & Diep and Sweeney 2008 \\
\hline 2 & Online Impulsive Buying & 6 & Mattila\&Wirtz, 2008 \\
\hline
\end{tabular}

Table 1: Number of items considered from various sources for the variables used in the research study

\section{Data Analysis}

SPSS (Statistical Package for Social Sciences) has been used to analyze the descriptive statistics of the respondents who make an online purchase using online shopping websites. To examine the moderating effect of age between hedonic shopping motivation and Online impulsive buying the Andrews Hayes Process was conducted and to analyze the association between age and hedonic shopping motivation, the Chi-Square test was conducted. The Cronbach Alpha Value was calculated to check the reliability, where the Cronbach Value is:0.890

\begin{tabular}{|c|c|c|}
\hline Demographic Variables & Frequency & Percentage \\
\hline \multicolumn{3}{|l|}{ Gender } \\
\hline \multirow{2}{*}{$\begin{array}{ll}\text { - } & \text { Male } \\
\text { - } & \text { Female }\end{array}$} & 215 & 51 \\
\hline & 206 & 49 \\
\hline \multicolumn{3}{|l|}{ Age (In Years) } \\
\hline \multirow{4}{*}{$\begin{array}{ll}\text { - } & 20-30 \\
\text { - } & 31-40 \\
\text { - } & 41-50 \\
\text { - } & \text { Above } 50\end{array}$} & 227 & 54 \\
\hline & 133 & 32 \\
\hline & 44 & 11 \\
\hline & 17 & 4 \\
\hline \multicolumn{3}{|l|}{ Occupation } \\
\hline \multirow{5}{*}{$\begin{array}{l}\text { - } \text { Students } \\
\text { - Own Business } \\
\text { - Employed in Pvt/Public/Govt } \\
\text { - Homemakers }\end{array}$} & 172 & 41 \\
\hline & 125 & 30 \\
\hline & 33 & 8 \\
\hline & 71 & 17 \\
\hline & 20 & 5 \\
\hline \multirow{7}{*}{ 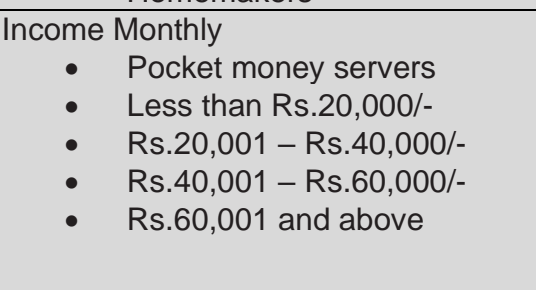 } & & \\
\hline & 154 & 37 \\
\hline & 65 & 15 \\
\hline & 106 & 25 \\
\hline & & \\
\hline & 34 & 8 \\
\hline & 62 & 15 \\
\hline \multirow{2}{*}{$\begin{array}{c}\text { Frequency Of Browsing Online } \\
\bullet \quad \text { Once Or Twice Daily } \\
\qquad \quad \text { Several Times Dailv }\end{array}$} & 61 & 15 \\
\hline & 60 & 14 \\
\hline
\end{tabular}




\section{GENERAL MANAGEMENT}

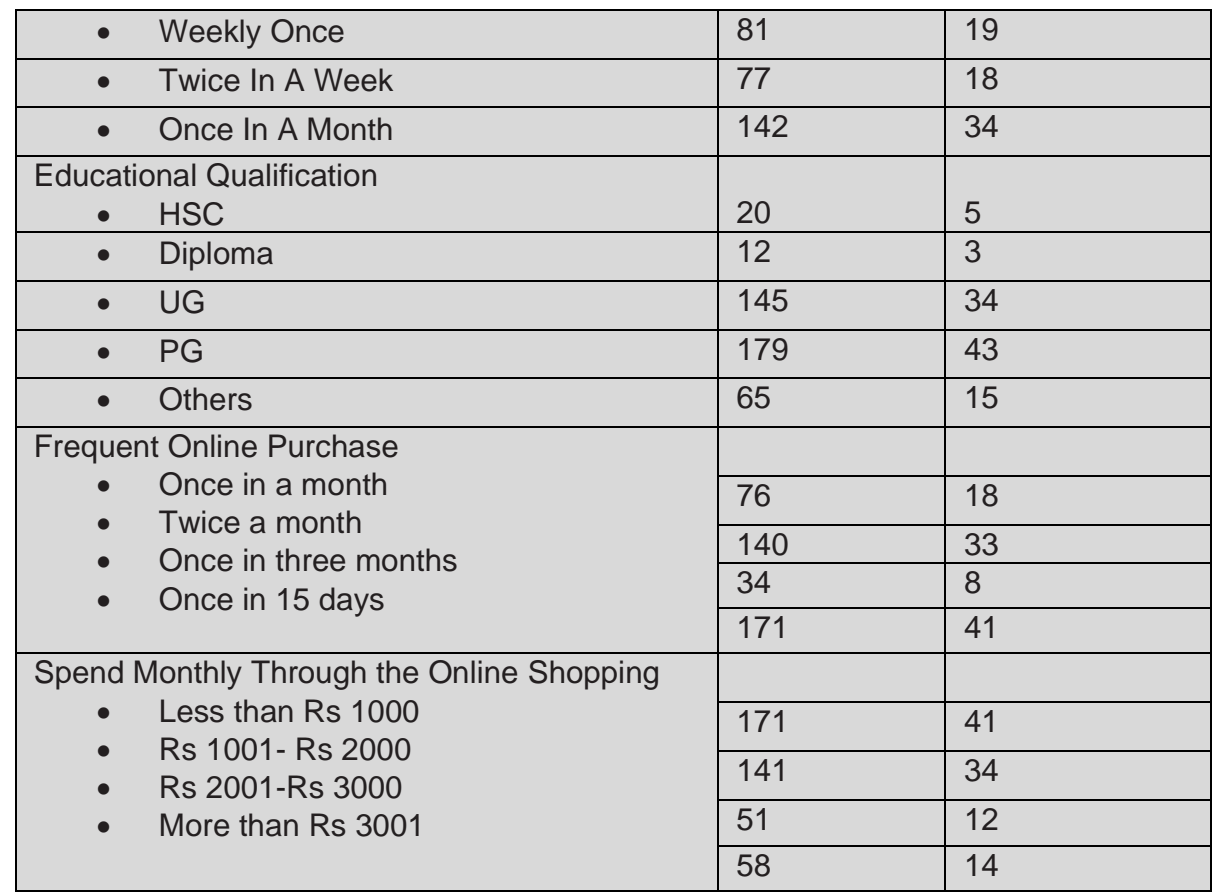

\subsection{Hypothesis Formulated for the Research Study}

\subsubsection{Moderating Effect of Age between Hedonic shopping motivation and Online Impulsive Buying}

Hypothesis

$\mathrm{HO}$ : There is no significant moderating effect of Age between Hedonic shopping motivation\& Online Impulsive Buying.
Andrew F Hayes Process
Model $=1$
$\mathrm{Y}=$ Online Impulsive Buying
$M=$ Age
$X=$ Hedonic Shopping Motivation

Result: Online Impulsive Buying

\begin{tabular}{|l|l|l|l|l|l|l|}
\hline $\mathbf{R}$ & R-sq & MSE & F & df1 & df2 & p \\
\hline .6335 & .4013 & 12.2117 & 93.1851 & 3.0000 & 417.0000 & .0000 \\
\hline
\end{tabular}

Table 2 Model Summary

Source: Primary data* $1 \%$ level of significance

\begin{tabular}{|l|l|l|l|l|l|l|}
\hline & Coefficient & SE & $\mathbf{t}$ & $\mathbf{p}$ & LLCl & ULCI \\
\hline Constant & 5.6790 & 1.6477 & 3.4467 & .0006 & 2.4403 & 8.9178 \\
\hline Hedonic Shopping Motivation & .4053 & .0573 & 7.0771 & .0000 & .2927 & .5178 \\
\hline Age & -1.0372 & .8087 & -1.2826 & .2004 & -2.6268 & .5524 \\
\hline Int_1 & .0186 & .0286 & .6497 & .5163 & -.0376 & .0748 \\
\hline
\end{tabular}

Table 2.1 : Direct Effect of Age on Hedonic shopping motivation

Source: Primary data

Int_1 : OIB xAge

\section{R-square increase due to interaction(s)}

\begin{tabular}{|l|l|l|l|l|}
\hline R2-change & F & df1 & df2 & P \\
\hline .0006 & .4221 & 1.0000 & 417.0000 & .5163 \\
\hline
\end{tabular}

Table 3 Direct Effect of Age on Online Impulsive Buying

Source: Primary data 


\section{GENERAL MANAGEMENT}

The above analysis derived from the Hayes processgives the moderating effect of Age between hedonic Shopping enjoyment and Online Impulsive Buying. To check the moderating effect the Hayes Model No: 1 was used to run the process using the SPSShaving a sample size of 421 . This model signifies thatthere is no moderating effect of Agebetween hedonic Shopping enjoyment and Online Impulsive Buying. The outcomes can be summed up, as referenced underneath.

The regression analysis illustrates that the model fit rundown shows the impact of every factor on the result variable. The observational examination inferred demonstrates that the outcomes show that the p-esteem isn't exceptionally huge appearance a p-worth of .5103 which is $<0.05$. Consequently, the invalid speculation is acknowledged, and the elective theory $\mathrm{H}$ is dismissed.

The confident interval given for the interaction term for the given model $(\mathrm{LLCl}=-.0376$ and $\mathrm{ULCl}=.0748)$ includes zero; hence it is been derived that there is no moderating effect of Age between Hedonic Shopping Motivation and Online Impulsive buying.

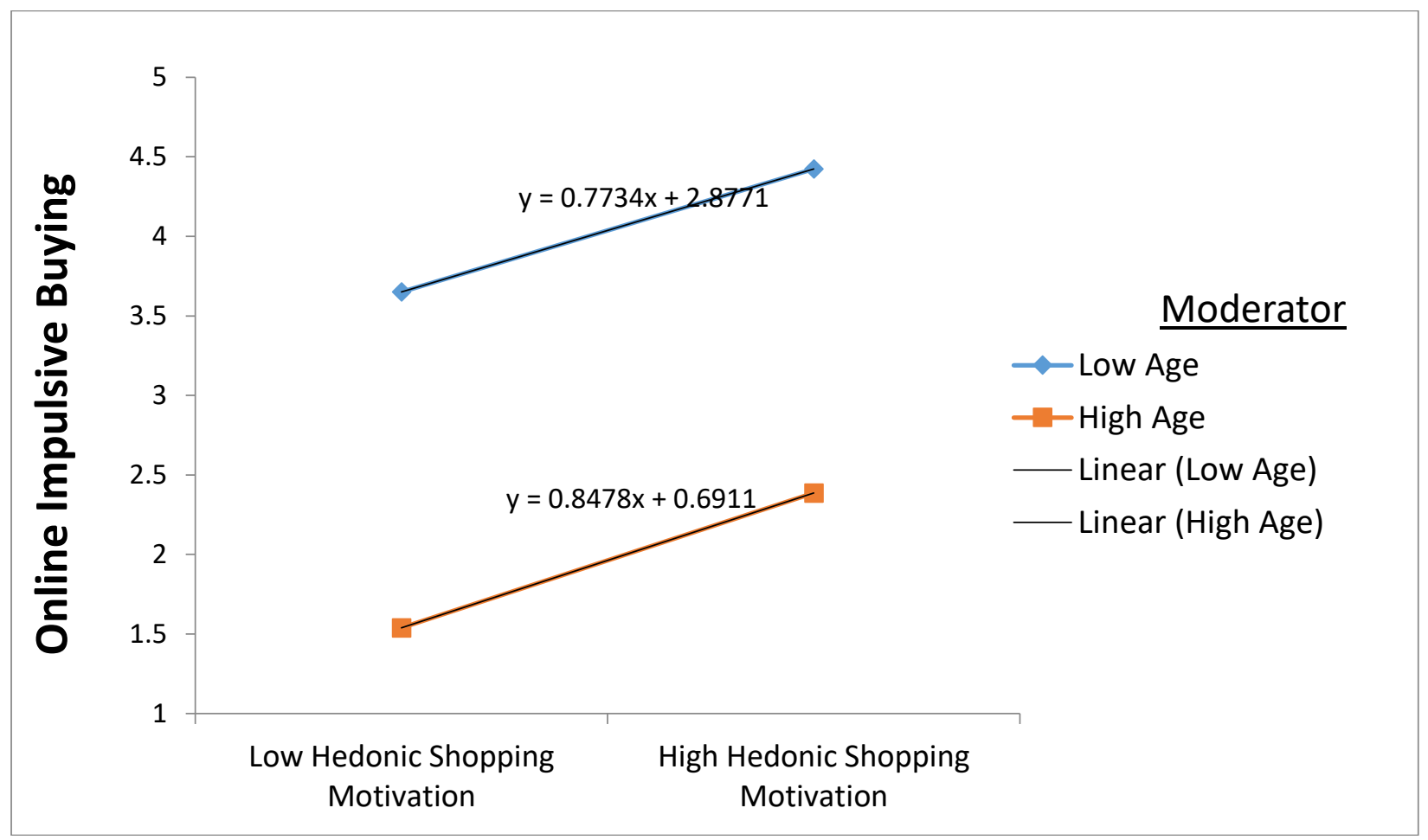

From the above graphical representation, it is marked that for the planned values, the value of Hedonic Shopping motivation for a given amount of Online Impulsive Buying. The graph gives a clear picture that there is no moderation effect of age Between Hedonic Shopping Motivation \&Online Impulsive Buying.

\section{Chi-square to find out the association between hedonic shopping motivation \& Online Impulsive Buying.}

\section{Hypothesis Framing}

Ho: Significant difference between hedonic shopping motivation and online impulsive buying.

$\mathrm{H} 1$ : No significant difference between hedonic shopping motivation and online impulsive buying.

\begin{tabular}{|l|l|l|l|}
\hline Chi-Square Tests & Value & df & Asymptotic Significance (2-sided) \\
\hline Pearson Chi-Square & $1208.480 a$ & 580 & 0.000 \\
\hline Likelihood Ratio & 747.461 & 580 & 0.000 \\
\hline Linear-by-Linear Association & 164.393 & 1 & 0.000 \\
\hline
\end{tabular}

Table 4: Results of Chi-square cross-tabulation test

Table 4 results theChi-square's significance level is 0.000 , i.e., $p<0.05$; therefore, we found that there is a significant differencebetween hedonic shopping motivation and online impulsive buying. Hence it is significant. That means $\mathrm{H} 1$ is rejected and it can be concluded that there is an association between hedonic shopping motivation and online impulsive buying. 


\section{Findings and Discussion}

\section{Demographic Statistics of the Respondents}

Table 6.1 shows that the female respondents are $51 \%$ than the male respondents $49 \%$. Based on age groups, respondents aged over 20-30 years have the highest percentage, which is 54 percent. Seen from the occupation level of the respondents, college-going students are frequently involved in online purchases with the help of online shopping with a percentage of 41 percent. Based on the Monthly income earned the respondents who are pocket money savers do online buying very often. Based on the frequency of browsing it was found that respondents shop online weekly once were the percentage is $19 \%$. Based on the education qualification respondents are having a PG education level of over 179 respondents which is $49 \%$. Based on the Frequent Online Purchase respondents purchase once in 15 days where the respondents are 171 which is $41 \%$. Based on the money spend monthly through Online Shopping respondents spend Rs 1000 and below through online shopping which the percentage is $41 \%$.

\section{Relationship Between Hedonic Shopping Motivation and Online Impulsive Buying}

Based on the study made the respondents enjoy their shopping when they make purchases online. When the customer has a hedonic motivation spirit which will automatically result in online impulsive buying. The customers engage themselves in online impulsive buying when the customers tend to full fill all the hedonic motivation pleasure and make sure that all their desires in purchasing the product online are been met. When desires are been met, there is emotional bonding between the hedonic motivation and the unplanned purchase. This study proves that there is no moderation effect on age between hedonic motivation and online impulsive buying. This study has coincided with the Study of (Akram 2018), which suggests that agedoes not affect hedonic motivation. The respondents have their stimulus to make their purchase, the customers are been influenced by the strategy the marketers use to attract the customers. The respondents of all age groups tend to make unplanned purchases. This result was supported by the article by (Wilma Laura 2020)purchasers may peruse with no expectation to purchase for no reason in particular or joy. Also, the hypothesis proves the impact of Hedonic Shopping motivation on online Impulsive Buying was upheld. This outcome is corresponding with the writing recommending a positive connection between gluttonous shopping inspiration and online imprudent purchasing

\section{Implications and Conclusion}

The current research study has practical and conceptual implications. This study has focused on hedonic shopping motivationand online impulsive buying through online shopping portals. The motivating spirit of the customers while they enjoy the shopping creates the environment to make an unplanned purchase. Much research has been conducted on impulsive buying with regards to the retail market but there are limited studies on online impulsive buying in the e-commerce environment. This study acts as the bridge to fill the research gap between the previous research studies (Hair 2013). The variables of online impulsive buying and hedonic shopping motivation are found to be significant. The finding suggests that hedonic motivation and online impulsive buying support each other by their valuable quality. The study concludes that the customers without a sense of motivation would be able to indulge themselves in the shopping and enjoy the shopping moment.

This study triggers online impulsive buying or an unplanned purchase, which often occurs in the minds of customers whenever they tend to see an offer or the display of the products showcased with a good e contented shopping portals, these features will influence the customers to make an unplanned purchase. (Faisal 2020)

The development of technology offers numerous advantages for shoppers in the motivation behindmaking purchasers simpler in satisfying their requirements and needs. Hedonic shopping motivation is major to human experience what's more, conduct. As the consequence of decadent pursuits, people enhance their abstract prosperity furthermore, start and keep up valuable practices. Nonetheless, enduring satisfaction of gluttonous inspiration is inconvenient because of versatile impacts. The online environment should empower the clients to have a free route over the items and consider the classifications of the clients and plan the site in a like manner. The web has changed the shopping example of the client where the plan, environment, site security draws in the clients and increment their fulfillment level. This affirmation will empower clients to make a subsequent buy and instigate them to make an online imprudent purchase.

\section{References}

[1] Akram, U., Hui, P., Khan, M., Yan, C. \& Akram, Z. (2018). Factors affecting online impulse buying: evidence from chinese social commerce environment. Sustainability. 10.352. $10.3390 /$ su10020352.

[2] Baber, H. (2019). E-servqual and its impact on the performance of islamic banks in malaysia from the customer's perspective. Journal of asian finance, economics and business. 6. 169-175. 10.13106/jafeb.2019.

[3] Faisal, M., Nabilah, K., Sadik, M., Hassian, U., Abidin, M. \& Ibrahim, K. (2020). Malaysian gen y and impulsive shopping behavior? Roles of hedonic shopping motivation. International journal of academic research in business and social sciences. 10. 10.6007/ijarbss/v10-i3/7051.

[4] Fang, J., Benjamin, G., Wen, C. \& Prybutoket V.R. (2016). "Consumer heterogeneity, perceived value, and repurchase decision-making in online shopping: The role of gender, age, and shopping motives." Journal of Electronic Commerce Research 17 (2), 116.

[5] Ha, H., Muthaly, S. \& Akamavialternative, R. (2010) Explanations of online repurchasing behavioral intentions. A comparison study of korean and uk young customers eur. J. Market., 44(6), 874-904.

[6] Hair, J. F., Black, W. C., Babin, B. J., Anderson, R. E., \& Tatham, R. L. (2013). Multivariate data analysis (vol. 7). Upper saddle river, nj: pearson prentice hall.

[7] Hashmi, H., Attig, S. \& Rasheed, F. (2019). Factors affecting online impulsive buying behavior: a stimulus organism response model approach. Market forces 14 (1). 19-42.

[8] Hussain, A., Ali, Z., Ullah, M. \& Rasool, F. (2021). A structured literature review on impulse buying: online jitters and offline jeepers. Humanities \& social sciences reviews, 9(3), 37-49.

[9] Ida, A., Miftachulhuda, A., Laxmilydia, E.\& Shankar, K.. (2020). Study of different types of customer experience competencies to drive growth of business organization. 7(1): 263-266.

[10] Li, N. \& Zhang, P. (2018). Consumer online shopping attitudes and behavior: an assessment of research. Electronic Commerce 


\section{GENERAL MANAGEMENT}

Customer Relationship Management. Retieved from

[11] file:///C:/Users/UsEr/Downloads/Consumer_Online_Shopping_At titudes_and_Behavior_An.pdf

[12] Mamuaya, N. \& Pandowo, A. (2018). The effect of the situational factor, store atmosphere, and sales promotion on hedonic shopping motivation and its implication on supermarket consumer impulsive buying in manado city. Journal of business \& retail management research. 13. 10.24052/jbrmr/v13is02/art01.

[13] Navitha, S. \& Vasantha, S. (2021). Mediating role of perceived quality between social media trust and purchase intention, Materials Today: Proceedings, Retrieved from

[14] https://scholar.google.com.tr/scholar?q=Materials+Today:+Proce edings,2021,ISSN+2214-

7853\&hl=en\&as_sdt=0\&as_vis $=1 \&$ oi $=$ scholart

[15] Ozer, L.\& Gültekin, B. (2014). Pre- and post-purchase stage in impulse buying: the role of mood and satisfaction. Journal of retailing and consumer services. 22. 10.1016/j.jretconser.2014.10.004.

[16] Pandey, S. \& Chawla, D. (2018), "online customer experience (oce) in clothing e-retail: exploring oce dimensions and their impact on satisfaction and loyalty - does gender matter?", international journal of retail \& distribution management, 46 (3), 323-346.

[17] Puntoni, S., R., Giesler M. \& Botti S. (2021). Consumers and artificial intelligence: an experiential perspective. Journal of marketing. 85(1):131-151. Doi:10.1177/0022242920953847

[18] Sahetapy, W. S., Kurnia, E. Y. \& Anne, O. (2020). The influence of hedonic motives on online impulse buying through shopping lifestyle for career women. SHS Web of Conferences 76(2):01057 Retrieved from

[19] https://www.researchgate.net/publication/341005144_The_Influe nce_of_Hedonic_Motives_on_Online_Impulse_Buying_through_ Shopping Lifestyle for Career_Women
[20] Salman, K. \& Sharifi, N. (2021). The role of cognitive and affective responses in the relationship between internal and external stimuli on online impulse buying behavior, journal of retailing and consumer services,volume $61(\mathrm{C})$. Retrieved from

[21] https://ideas.repec.org/a/eee/joreco/v61y2021ics0969698921001 338.html

[22] Samo, A., Shaikh, H., Bhutto, M., Rani, F., Samo, F. \& Bhutto, T. (2019). Young buyers: shopping enjoyment and obsessivecompulsive buying. European Journal of Business and Management, 11(3), 129-139.

[23] Sari, N. \& Hermawati, S. (2020). The effect of shopping lifestyle, hedonic shopping motivation, and sales promotion on impulse buying behavior in e-commerce (case study of berrybenka consumer). Jurnalilmiahekonomibisnis. $25.45-54$. 10.35760/eb.2020.v25i1.2343.

[24] Sharma, P., I. Chen, \& S. Luk. (2012).Gender and Age as Moderators in the Service Evaluation Process," Journal of Services Marketing, 26(2), 102-114.

[25] Wahab, Z., Shihab, M., Hanafi, A., \& Mavilinda, H. (2018). The influence of online shopping motivation and product browsing toward impulsive buying of fashion products on a social commerce. Jurnal Manajemen Motivasi. 14(32). 10.29406/jmm.v14i1.1030.

[26] Yistiani, N.N.M., Yasa, N.N.K. \& Suasana, I.G.A.K.G. (2012) Pengaruh Atmosfer Gerai Dan Pelayanan Ritel terhadap Nilai Hedonik Dan Pembelian Impulsif pelanggan Matahari Department store Duta Plaza di Denpasar. Jurnal Manajemen, Strategi Bisnis Dan Kewirausahaan, 6(2), 139-149.

[27] Yu-qianzhu, D. \& David, C. Y., (2020). Celebrity endorsement and impulsive buying intentions in social commerce - The case of instagram in Indonesia: Celebrity endorsement. Journal Of Electronic Commerce in Organizations (JECO), 2020. 18(1), 117 